\title{
PENYULUHAN DAN PEMBERIAN LEMBAR BALIK TENTANG KESEHATAN REPRODUKSI MODIFIKASI ISLAMI DI SMK MUHAMMADIYAH
}

\author{
Yossy Wijayanti ${ }^{1}$, Diny Vellyana ${ }^{2}$ \\ ${ }^{1}$ Fakultas Kesehatan Universitas Muhammadiyah Pringsewu Lampung \\ ${ }^{2}$ Fakultas Kesehatan Universitas Muhammadiyah Pringsewu Lampung \\ Email : (yossywijayanti@ umpri.ac.id ${ }^{1)}$
}

\begin{abstract}
Remaja akan semakin tumbuh, berubah, berkesempatan dan segala hal yang berkemungkinan terjadi pada remaja hingga sampai pada kemungkinan beresiko mengalami masalah pada kesehatan reproduksi. pada kitab suci alqur'an surat An Nur ayat 30 yang dijadikan pedoman bagi umat islam menerangkan hukum berperilaku secara islam memiliki arti berikut ini, katakanlah kepada orang laki -laki yang beriman:"hendaklah mereka menahan pandangannya, dan memelihara kemaluannya; yang demikian itu adalah lebih suci bagimereka, sesungguhnya Allah Maha Mengetahui apa yang mereka perbuat.Pengabdian masyarakat ini bertujuan untuk memberikan penyuluhan kesehatan reproduksi dengan modifikasi islami yang dapat menjadikan perilaku remaja SMK Muhammadiyah Pringsewu menjadi lebih baik lagi. Metode kegiatan penyuluhan menggunakan lembar balik tentang kesehatan reproduksi modifikasi islami di SMK Muhammadiyah Pringsewu dengan pemberian ceramah atau penjelasan kepada peserta secara jelas. Hasil evaluasi menunjukkan para peserta siswa SMK Muhammadiyah Pringsewu seluruhnya memahami perilaku yang baik dan islami dalam menjaga kesehatan reproduksi.
\end{abstract}

Kata Kunci : Kesehatan Reproduksi, Modifikasi Islami

\section{Pendahuluan}

Beberapa perilaku yang mungkin terjadi pada usia remaja adalah perilaku berisiko pada seksualitas. Pemecahan masalah pada kasus kesehatan reproduksi remaja dapat dilakukan melalui pendekatan pendidikan kesehatan reproduksi modifikasi berbasis islami. Seperti yang telah dijelaskan pada kitab suci alqur'an surat An Nur ayat 30 yang dijadikan pedoman bagi umat islam menerangkan hukum berperilaku secara islam memiliki arti berikut ini, katakanlah kepada orang laki -laki yang beriman:"hendaklah mereka menahan pandangannya, dan memelihara kemaluannya; yang demikian itu adalah lebih suci bagimereka, sesungguhnya Allah Maha Mengetahui apa yang mereka perbuat.

Data situasi kesehatan reproduksi remaja yang didokumentasikan melalui proses wawancara bersumber dari Survei Demografi dan Kesehatan terutama komponen kesehatan reproduksi remaja (KRR), usia remaja yang diwawancarai adalah antara $15-24$ tahun dan belum menikah. Pada remaja usia $15-19$ tahun, proporsi terbesar berpacaran pertama kali pada usia 15 - 17 tahun.sekitar $33.3 \%$ remaja perempuan dan 34.5\% remaja laki - laki yang berusia 15 - 19 tahun mulai berpacaran pada saat merekabelum berusia 15 tahun. Pada usia tersebut mereka belum bisa dipastikan sudah memiliki keterampilan hidup (life skills) yang memadai, pengalaman yang cukup, pemahaman dan ilmu agama yang masih sedikit sehingga mereka berisiko memiliki perilaku pacaran yang tidak sehat, atau biasa disebut dengan perilaku seksualitas yang tidak baik hingga 


\section{BAGIMU NEGERI : JURNAL PENGABDIAN MASYARAKAT}

P-ISSN : 2548-8651 | E-ISSN : 2548-866X

Email : ejournal@umpri.ac.id

melakukan hubungan seks pra-nikah (SDKI Kesehatan reproduksi Remaja, Badan Pusat Statistik, 2012).

Berdasarkan latarbelakang diatas menjadi pertimbangan pentingnya pemberian penyuluhan tentang

\section{Metode}

Metode kegiatan penyuluhan dan lembar balik tentang kesehatan reproduksi modifikasi islami di SMK Muhammadiyah Pringsewu dengan pemberian ceramah atau penjelasan kepada peserta secara jelas dimulai dari pengertian, tujuan, manfaat dan langkah langkah dalam menjaga kesehatan reproduksi modifikasi islami. Kegiatan ini berlangsung dimulai dari proses perizinan, pesiapan materi dan bahan, kontrak pengabdian kepada peserta dan penyampaian materi. Pada proses penyampaian penyuluhan terlebih dahulu peserta diberikan pertanyaan terbuka terkait kesehatan reproduksi, kegiatan ini disebut dengan apersepsi. Setelah apersepsi selanjutnya adalah penyampaian materi dengan cara ceramah dan memperlihatkan media lembar balik. Setelah materi disampaikan dilakukan tahap tanya jawab peserta dan dilanjutkan evaluasi materi untuk melihat apakah materi dapat diterima oleh peserta dengan baik.

\section{Hasil Dan Pembahasan}

\section{Hasil}

Penyuluhan dan pemberian lembar balik tentang kesehatan reproduksi modifikasi islami di SMK Muhammadiyah mendapatkan hasilsebagai berikut:

a. Terdapat peningkatan pengetahuan siswa SMK Muhammadiyah Pringsewu tentang kesehatan reproduksi modifikasi islami

b. Peningkatan pemahaman siswa tentang perilaku seksual yang mempengaruhi kesehatan reproduksi

\section{Pembahasan}

Pemberian penyuluhan dengan menggunakan lembar balik tentang kesehatan reproduksi modifikasi islami kepada siswa SMK Muhammadiyah Pringsewu Lampung menghasilkan dampak yang efektif bagi peningkatan pengetahuan kesehatan reproduksi dan perilaku siswa remaja.

Kesehatan reproduksi modifikasi islami ini memberikan pengetahuan tentang kondisi sehat pada organ resproduksi islami dengan cara menghindari perilaku perilaku seksual siswa yang berbahaya melalui modifikasi islami yaitu dengan cara menambahkan dan mengkaitkan pemeliharan kesehatan reproduksi secara islami dan perilaku dalam menjaga kesehatan reproduksi sesuai dengan hadist dan al - quran.

Pada proses pemberian penyuluhan ini siswa diminta untuk mendengarkan penyuluhan terlebih dahulu hingga kemudian diberikan waktu untuk bertanya dan berdiskusi. Selama proses penyuluhan para siswa dengan antusia mengikuti dan memberikan beberapa pertanyaan yang berkaitan dengan perilaku yang menjaga kesehatan reproduksi. Penyuluhan kesehatan dengan modifikasi islami ini sangat memberikan arti penting dikarenakan mengembalikan segala perilaku kepada al quran dan hadist, seperti HR. Ath Thabrani yaitu yang berisi tentang perilaku 


\title{
BAGIMU NEGERI : JURNAL PENGABDIAN MASYARAKAT
}

\author{
P-ISSN : 2548-8651 | E-ISSN : 2548-866X \\ Email : ejournal@umpri.ac.id
}

seksual yang mempengaruhi kesehatan reproduksi akan mendapatkan laknat dari Allah SWT.

Menurut Notoadmodjo (2014) pendidikan kesehatan adalah suatu penerapan konsep pendidikan di dalam bidang kesehatan. Pendidikan kesehatan merupakan suatu kegiatan untuk memberikan atau meningkatan pengetahuan masyarakat dalam memelihara dan meningkatkan kesehatan. Konsep dasar pendidikan merupakan suatu proses belajar, yang berarti di dalam pendidikan terjadi proses perkembangan atau perubahan ke arah yang lebih dewasa, lebih baikdan lebih matang pada diri individu, kelompok atau masyarakat, dari tidak tahu tentang nilai - nilai hidup di dalam masyarakat selalu memerlukan bantuan orang lain yang lebih dewasa, lebih mampu, lebih tahu dan sebagainya. Pada tahap perkembangan tersebut dapat mempengaruhi perilaku kesehatan reproduksi remaja yang secara syariat agama islam memiliki ketentuannya, seperti dalam surah An Nur 30 "Katakanlah kepada orang laki-laki yang beriman: "Hendaklah mereka menahan pandangannya, dan memelihara kemaluannya; yang demikian itu adalah lebih suci bagi mereka, sesungguhnya Allah Maha Mengetahui apa yang mereka perbuat".(QS An Nur 30). Selain itu perilaku reproduksi yang dilakukan oleh remaja muslim seharusnya berdasarkan firman Allah SWT berikut ini "Dan janganlah kamu mendekati zina; sesungguhnya zina itu adalah suatu perbuatan yang keji. Dan suatu jalan yang buruk (QS Al Isra 32).

\section{Simpulan Dan Saran}

Setelah diberikan pendidikan kesehatan reproduksi dapat disimpulkan bahwa selama proses ini tidak ditemui kendala yang berarti pada saat dilakukan pendidikan kesehatan reproduksi. Pada proses pemberian penyuluhan ini siswa diminta untuk mendengarkan penyuluhan terlebih dahulu hingga kemudian diberikan waktu untuk bertanya dan berdiskusi. Selama proses penyuluhan para siswa dengan antusias mengikuti dan memberikan beberapa pertanyaan yang berkaitan dengan perilaku yang menjaga kesehatan reproduksi. Penyuluhan kesehatan dengan modifikasi islami ini sangat memberikan arti penting dikarenakan mengembalikan segala perilaku kepada al - quran dan hadist, seperti HR. Ath Thabrani yaitu yang berisi tentang perilaku seksual yang mempengaruhi kesehatan reproduksi akan mendapatkan laknat dari Allah SWT. Oleh karena itu untuk meningkatkan kualitas kesehatan reproduksi remaja sebaiknya program pendampingan harus dilakukan secara rutin dan berkala.

\section{Daftar Rujukan}

Q.S An Nur Ayat 30

SDKI. (2012). Survey Demografi dan Kesehatan Indonesia. Jakarta; Badan Pusat Statistik

Notoadmodjo, S. (2014). Ilmu Perilaku Kesehatan. Jakarta: Rineka Cipta

HR. At - Thabrani

Bowo, I., ... A. S.-P. S., \& 2021, undefined. (2021). Sosialisasi Uji Etik Penelitian Kesehatan Mahasiswa Berbasis IT di Universitas Muhammadiyah Pringsewu.

Jurnal.Darmajaya.Ac.Id, 13-17.

https://jurnal.darmajaya.ac.id/index.php/PSND/article/view/2924 